\title{
Plant Parasitic Nematode Threat to Nigerian Agricultural Food Security
}

\author{
Aghale, D. N , Egbucha, K.C ${ }^{1}$, Umeh, O.J ${ }^{2}$ \\ 1. Department of Plant Science and Biotchnology, Michael Okpara University of Agriculture, Nigeria \\ 2. Department of Rural Sociology and Extension, Michael Okpara University of Agriculture, Umudike
}

*Corresponding Author: Aghale, D. N, Department of Plant Science and Biotchnology Email: aghaleduka@yahoo.com

\begin{abstract}
It has been estimated that between 20 - 40\% of global productivity are lost as a result of direct yield losses caused by pests and pathogen and if some of this food crops could be saved from pest attack, it could be used to feed the malnourished in the country. Plant parasitic nematodes are of such disease agent on many cultivated crops which are widely distributed throughout the world and are capable of causing damage to most, if not for all crops and their scourge has made it difficult to provide food in adequate quantity and of the right quality for the growing population of the nation.This paper reviews the general economic effect of plant parasitic nematode on food crops, the history and distribution in Nigeria also the possible control measures to checkmate root knot nematode menace in Nigeria with the view of increasing food production.
\end{abstract}

Keywords: Plant parasitic nematode, food insecurity, crop losses and control measures.

\section{INTRODUCTION}

The contributions of agriculture to national growth and development could not be under estimated. Nigerian agricultural sector contributes between $30-42 \%$ and employs $65 \%$ of the labour force and has been describe as the most important sector of the economy which holds a lot of potentials for the future economic development (10) ( Emeka, 2007). It has been estimated that between $20-40 \%$ of global productivity are lost as a result of direct yield losses caused by pests and pathogen (19)( Oerkeet al., 1994]. If some of this food could be saved from pest attack, it could be used to feed the malnourished in the country. This therefore shows that in the absence of proper protection activities, pests have the potentials to hinder increased agricultural productivity as well as all the benefits that come with such increase, thus resulting into food insecurity. The importance of pests and diseases in crop production has increased tremendously; their scourge has made it difficult to provide food in adequate quantity and of the right quality for the growing population of the world. Crops and their products provide $57 \%$ of the total value of agricultural productionin developing countries and the sustainability of intensified crop based system is threatened by buildup of soil borne constraints, particularly plant parasitic nematodes.

The final report of the 1996 world food summit states that food security exist when all people, at all times have physical and economic access to sufficient, safe and nutritious food to meet their dietary needs and food preferences for an active and healthy life. That is to say, having access by all people at all times to enough food for an active healthy life. Since food security has been referred to as the availability of food and one's access to it, a household is considered food secured when its occupants do not live in hunger or fear of starvation. Food availability, food utilization and food access are the principle variables that define household security.

Food insecurity is the state of being without reliable access to a sufficient quantity of affordable, nutritious food. Food insecurity results into people suffering from chronic hunger and poor nutrition thus less likely to have healthy and productive lives.

In Nigeria, half of the native's food supply is lost to the activities of crop pests, diseases and weed. The root knot nematode and other species of nematodes have been identified as the most economic 
pests of crops which have resulted into a loss range of $25 \%$ to $100 \%$. (23)Onyenobi, (1992) reported $25 \%$ losses in yam tubers produced due to the activities of root knot nematode while yield losses as great as $12.5-18$ tons/hahas been reported in banana, 10-89\% for tomatoes and $74-78$ and $100 \%$ in pepper production (28)(Sogut and Elekeioglu, 2007). Root knot nematode was documented as a major constraint to large scale soybean production (6) (Atungwuet al., 2012.)Their infestation often results into economic and socio-economic problems arising from low protein intake, insufficiency in food supply, increase in cost of living as well as cost of production.

Nematodes parasites almost on all plants on earth, feeding on their roots,stems, leaves, flowers, buds and seeds where they cause lots of diseases that result in substantial declines in food production or total crop failure. The most common destructive plant parasitic nematode in Nigeria include the root knot (Meloidogyne species] which causes total failure of the kenaf crop in Ibadan in the 60s and the root lesion nematodes that cause up to $27 \%$ decline in maize production in most parts of the South Western zone of Nigeria(7) (Egunjobi, 2014.]

In this way, nematodes contribute substantially to hunger all over Nigeria.Undoubtedly, they are wide spread pest and frequently the most insidious, costly and periodically result in crop devastation with its attendance economic misery. Thus rub the farmer the fruits of his labour and leaves him hungry and miserable.

Objectives of the study.

The objectives of this review were to understand the

History and distribution of root knot nematode in Nigeria

Access the general economic effect of plant parasitic nematode on food crops

Control measures to checkmate root knot nematode menace in Nigeria.

\section{History AND Distribution OF RoOT KNOT NEMATOdE IN NigERIA}

Plant parasitic nematodes are of such disease agent on many cultivated crops which are widely distributed throughout the world and are capable of causing damage to most, if not for all crops. On a global scale the distribution of nematode species varies greatly. Some are cosmopolitan, such as certain Meloidogynespp, while others are particularly restricted geographically e.g. Nacobbusspp. or are highly host specific, such as Heteroderacarotaewhich attacks only carrots. Some crops may have very few nematode pests while others have a particularly wide range of genera and species associated with them, such as sugar cane and rice, leading to difficulties for nematode control strategies. Three of the nematodes that are of economic importance in Nigeria are the endo- parasitic root-knot nematodes (Meloidogyne) species, root lesion nematodes (Pratylenchulus species) and the cyst nematodes (Heterodera). These are ranked the world most devastating plant parasitic nematodes(26) (Sasser 1989).

Root-knot nematodes are plant-parasitic nematodes from the genus Meloidogyne which exist in soils with hot climate or short winters. (9)Eisenback and Triantaphyllou, (1991) reported that four Meloidogyne species(M. javanica, M. arenaria, M. Incognita and M. hapla) are the major nematode pest world- wide. According to (20)Ogbuji (1976), host plants of Meloidogyne species are estimated at over 2000 plants and these include permanent crops, cereals and weed plants. Although Meloidogyne species may have such a wide host range, a single species may have specific preference for some plant hosts that differ from that of another species.

The root- knot nematodes (Meloidogyne incognita, M. javanica, M. arenaria) were first reported in Nigeria on cowpea in 1958 and documented in 1960 (Anon., 1961). These root-knot nematodes have been found widely distributed in irrigated and upland conditions in Nigeria, with M.incognita occurring predominantly in the southern forest zones and $M$. javanica in the northern savanna zone. M. arenaria is rare but more common in the southern zone than in the northern zones (21) (,Olowe, 1976). (22)Onyenobi, (1996) reported that only two species of root- knot nematodes attack yam in Nigeria (M. incognita and M. javanica.).M. incognita is more frequently than $M$. javanica in the low land south eastern areas of tropical rain forest zone of Nigeria, while $M$. javanica is more in the middle belt states of the Guinea savanna zone, a relatively high altitude zone. $M$ incognita, $M$. javanica, and $M$. arenaria have been reported with $M$. incognita being most commonly distributed. A study of 500 live populations of Meloidogyne species collected from different regions reviews that $M$. 
incognita was present in 54\% of population, $M$. javanica in 30\%; M. hapla in $7 \%$ and M. arenaria in $7 \%(26)($ Sasser,1989) and that these four species probably cause more damage than all the other Meloidogynespp combined.

Spread of plant parasitic nematodes has been reported by (18)Nwauzor, (1982) as short range, medium range and long range. Short range is spread within a small area and through the nematode's own power of locomotion.Medium range spread is between fields, while long range spread is from one state or region to another and human activities are major means of spread in both medium and long range spread.

\section{ACCESS the General ECONOMic EFFeCt OF RoOT KNOT Nematode}

Plant parasitic nematodes especially the root knot nematodes (Meloidogyne) have gained international recognition as one of the most serious constraints to increase crop production especially in the developing nations. A significant aspect of the root knot nematode problems in tropical Africa is the rapidity with which the problem becomes severe. Accurate figures on crop losses attributed to Meloidogynespp are difficult to come by and Crop loss estimated due to nematodes in some crops, such as cowpea, cotton, okra, tomato, tobacco, banana, maize, etc range from $20-100 \%$ in different parts of the world(12) (Fawole,1992).Crop losses range from slight less than 1\% to total destruction while the degree of damage depends upon the population density, susceptibility of the crop, and environmental conditions such as fertility, moisture and presence of other pathogenic organisms which may interact with nematodes (26)(Sasser, 1989). Further reported that estimated overall annual yield loss of the world's major crops due to damage by plant parasitic nematode was $12.3 \%$,and for the 20 life - sustaining crops (LSC) that serve as man's primary food sources estimated annual yield loss of $10.7 \%$ losses of life sustaining crops grown in developing countries compared with those in developed countries were $12.6 \%$ and $7.0 \%$ respectively.In crops like cassava, $8.4 \%$ yield losses while in citrus it is $14.2 \%$, cocoa is $10.5 \%$, maize is $10.2 \%$, cotton is $10.7 \%$, groundnut $12 \%$, potato $12.2 \%$, rice $10.0 \%$, sorghum $6.9 \%$, soya beans $10.6 \%$, sugar cane $15.3 \%$, wheat $7.0 \%$, tobacco $14.7 \%$ and sweet potato $10.2 \%$ (11)(FAO, 2006). (1)Adesiyan, et al., (2000) reported that accurate yield loss data are not available for most crops in Nigeria and many other nations. However, investigation on tomato, maize and cowpea has shown yield reduction of $28-64 \%$ indicating the destructiveness of plant parasitic nematode and its importance in food security. Losses caused on a wide range of agricultural food crops both direct and indirect damage by root knot nematode results in delayed maturity, toppling, reduced yield and quality of crop produce, high cost of production and loss of income. The yield reduction in nematode attack can pass un - notice at $20-30 \%$ losses especially in maize, cowpea, sorghum, sugar cane, citrus and vegetables while in root and tuber crops, disfiguration does not only lowered the market value of the produce but also results in consumer's rejection. The overall effect of all these is that there is a reduction in quality and quantity of farm produce such as in yam where galled tubers shown a reduction of $39-52 \%$ in price and loss more weight than the healthy tubers in storage (17)(Nwauzor and Fawole 1992). Nematodes damage is an important factor in tuber quality, reduction of yield and general losses in yam both in the field and in storage. A large number of plant nematodes associated with yam cultivation have been reported from various yam producing areas of the nation.

Crop loss of $40 \%$ has been reported in irrigated areas in Nigeria with $10-89 \%$ losses for tomato(17) ( Nwauzoret al., 1992). It is therefore pertinent to note that crop losses caused by nematode disease are more serious in warmer areas and areas where food and fibre are scarce.Losses that result from nematode attack may not necessarily be as a consequence of direct cell death, necrosis or 'diseased' tissue but may derive from other more insidious aspects, such as interference with the root system, reducing their efficiency in terms of access and uptake of nutrients and water; to the unaware, nematode-affected plants present typical drought and nutrient stress symptoms, which are easily and often misdiagnosed. On Musa spp. (bananas and plantains) nematode damage affects root efficiency on the one hand, but additionally leads to root necrosis and death, undermining plant anchorage; heavily infected bunch-bearing plants can topple due to poor root anchorage leading to total loss of the unripe fruit (13)(Gowenet al. 2005).

Several species of root knot nematodes including $M$. incognita and $M$. javanicahave been detected at damaging levels in almost all maize growing regions ofthe world (15)(McDonald and Nicol2005). $M$. africanaand $M$. arenariahave been recorded on maize in India and in Pakistan, and $M$. arenariahas also been reported by several authors from the USA(15) (McDonald and Nicol2005). Above ground 
symptomsinclude stunting, leaf chlorosis and patchy growth. Root galls may be small or large, terminal or sub-terminal or in some cases totally absent. For this reason maize has often mistakenly been considered a poor host or even a non-host for root knot nematodes(15) (McDonald and Nicol 2005). In Nigeria, $P$. brachyurus has been reported to be responsible for a $28.5 \%$ yield reduction, with this reduction being correlated with a 50\% increase in nematode density (8) (Egunjobi 1974).

(1)Adesiyanet al., (2000) reported that it has been difficult to quantify the amount of economic losses caused by root-knot nematodes, especially in developing countries where crops are rarely grown as sole- crops. Besides, plant- parasitic nematodes exist in soil as mixed populations where other pathogens such as bacteria, fungi and virus are often found on the same plants on which the nematodes are feeding.

\section{Control Measures to Checkmate Root Knot Nematode Menace in Nigeria}

Several approaches have been considered for the control of plant parasitic nematodes, but the most favoured approach that gives immediate solution has been the use of nematicides, in spite of the concern for environmental pollution and pesticide residues. The other methods of control are the use of resistant varieties, cultural and land management, integrated pest management and of recent the use of ethno medicinal plants (Botanicals).Cultural control methods have been the appropriate method for the Nigerian farmers and this include crop rotations, bush fallow, mulching, plowing during dry season, the use of trap crops and flooding of farm sites. Crop rotation is the most effective cultural method in managing nematode pests and it involves inter-planting with non-host crops, poor hosts or those with resistance or tolerance to root- knot nematodes in alternate with a susceptible crop. (5)Atu\&Ogbuji (1982) reported Amaranthusspp, Citrulluslaratus, Zea mays, Manihotspp and the highly resistant Mucunaprurians are the crops used in rotation sequence. But no cropping sequence which includes crops that suppress root-knot nematodes has been adopted by farmers.

There exists a vicious circle of nematode introduction by the use of contaminated plant materials on uninfected soil which results in both infestation of new plant and soil. Another most desirable and economical cultural method for nematode control is the use of resistant varieties. Some cultivars are bred for resistance or are naturally resistant to nematode pests. Resistantcultivar produce the most dramatic increase in yield of many crops and holds the solution to most nematode problems, particularly with the recent increase in research on gene transfer. However, the solution is more apparent than real since it is clear that such cultivars show resistance to only a limited number of nematode genera. However, Onyenobi (1992) reported that known resistant varieties of yam are few and are mostly species and cultivars that are in low demand by consumers and that resistance in yam cultivar is conferred to nematode species of different genera to more than one species from the same genus to single species

Inter cropping is another cultural method of control and is practiced by most small holder farmers that produce the bulk of food crops in the country.(4)Atu , (982) reported that most of the traditional inter crops such as Hibiscusesculentum, Corchorusolitorus, and Cucurbitapepo are highly susceptible to root- knot nematodes and remarked that mixed cropping with other host crops of Meloidogynesppalongside yam plant is likely to increase the nematode populations and its severity of damage. Although growing different crops on the same piece of land in a random fashion results into minimal damage on a very susceptible crop. Therefore, peasant farmers have less nematode problems in contrast to locations where modern agriculture is practiced as sole cropping in Nigeria.

Chemical is an effective method of nematode control and the use of synthetic nematicides have been the most effective means of control in crop production. (22)Onyenobi, (1996)pre- treated seed yams with oxamyl to control biodeterioration prior to planting and obtained positive results. The environmental hazards associated with these chemicals are well documented and are being increasingly highlighted which have resulted into deregistration of the chemicals. Chemical nematicides are increasingly being questioned as a result of rapid resistance developed on their target organisms and the use of synthetic pesticides is associated with myriads of problems which include the high cost of nematicides and skill needed in its application techniques.Every nematicide application is accompanied by health hazard and(27)Schmidt, (1986) reported increase in sterility and birth defects in South East Asia as a result of nematicide applications and usage. And also reported that many of these pesticides are adsorbed in the soil, particularly in the humus layer and their presence directly or indirectly influences the micro fauna in the soil which alter organic matter 
decomposition and nutrient circulations. Soil organisms such as earth worms suffer strong toxic reaction due to the use of chemical nematicides. It was reported that 50,000 hectares of banana plantations in Costa Rica were rendered permanently unusable for cultivation as a result of chemical control of Radophilus nematodes.

Botanicals have been considered in the control of plant parasitic nematodes based on the negative effects of synthetic nematcicde.This approach is informed by the fact that conventional nematicides are out of reach of resource poor farmers and that Neem and few other plants have successfullybeenused for control and are compatible with Intergraded Pest Management strategies which are acceptable to farmers who prefer low input technologies. In recent years, the neem tree Azadirachtaindica has been used as a cheap source of nematcideand thenematicidal properties has been reviewed(14) (Jacobson, 1988). Other plants such as Crotolaria and Piper nigrum are currently being assessed and the added advantages of environmental safety make plant extracts preferable to other chemical nematicides. Farmers, especially the poor ones have used botanicals successfully for the protection of crops against pests and diseases either in the field or in their stores and the farmers will therefore accept proven botanicals for the control of root-knot nematodes in crop production.(24)Salako, (2002) stated that the use of botanicals 'has obvious advantages which include its relative cheapness, complex mixture of active ingredients that function differently on various parts of the pest life cycle and physiology that makes it difficult for pest to develop resistance. (30)Yaradua, (2007) submitted that botanical pesticides are simple to prepare, locally renewable, users friendly and environmentally safe.

(7)Egunjobi(2014) reported that several plants have been identified with nematicidal or nematostatic properties either in the seeds, fruits, leaves, barks, roots or in their root exudates and on the use of common agro wastes of cassava and cocoa to reduce the infestation of Meloidogyne species on cowpea. (3)Amosu (1981) tried root extract of Chromoleanaodorata, Ricinuscommunis, Lycopersicumesculentum and Vignaunguiculata with success against Meloidogynesppin- vitro. (24)Salawu, (1992) reported that Azadirachtaindica, Chromolaenaodorata, and Amnonamuricata were very effective against the eggs of Heteroderasachari from hatching. (2)Aghale, (2011) reported that both $A$. indica and $P$. nigrum are favourable alternatives to synthetic pesticides on yam production and in storage and that both plants are locally used in ethno medicinal practices without toxicological residues.

\section{CONCLUSION}

The contributions of agriculture to national growth and development could not be under estimated. The cultivation of food crops in Nigeria stands a serious risk of decline in production due to the activities of plant parasitic nematodes which are abundant in our soils. Root and tuber crops which dominate Nigerian agricultural production accounts for 89 metric tons in 2008 and amount to more than two third of staples grown which are highly prone to root knot nematode attack. Farmer's awareness about the problems of plant parasitic nematodes and their management effect should be emphasized because in the absence of proper protection activities, nematode have the potential to hinder increase productivity as well as the benefits that goes with it in this population explosion era. Farmers should be able to identify nematode problems in their areas for them to appreciate any positive measure of control and this goal has not been achieved due to high level of illiteracy and lack of technical expertise on the field of nematode studies. Control measures using chemicals are very expensive for the resource poor farmers whose operations go with little profit margins, hence the reliance on cultural methods. Future emphasis should be based on this method that is less expensive and without any specialized skill in nematode control.

\section{REFERENCES}

[1] Adesiyan, S.O.,F.E Cavenss., M.O Adeniji., B. Fawole (2000). In Nematode pests of Tropical crops. Pp3.

[2] Aghale, D.N 2011. Evaluation of botanicals in the control of Root Knot N ematode, M. incognita in yam production

[3] Amosu. J.O 1981.Control of root knot nematodes by cultural practices. In International proceeding $3^{\text {rd }}$ Imp. Res. Plan conference on root knot nematode M. spp. Nov, 16-20, 1981 Ibadan, Nigeria. Pp263 
[4] Atu U.G, 1982. Population studies, pathogencity and control of root knot nematode Meloidogynespp on D. rotundata (poir).Ph.D thesis, UNN, Pp 119.

[5] Atu, U.G \& R.O. Ogbuji1982. Root knot nematode susceptibility of crops grown with yam in Nigeria. Proceedings of the $2^{\text {nd }}$ triennial symposium of the International Society of Tropical Agric, Africa branch held in Doualla, Cameroun. 14-19, august 1982.

[6] Atungwu, J.J., Lawal, M.O., Afolami, S.O and Adejuyigbe, C.O. 2012. Appraisal of composts for suppression of Meloidgynespecies and enrichment of micro arthropods in soybean fields, Biological Agriculture \& Horticulture. An International journal for sustainable production system.

[7] Egunjobi, O. A 2014.Nematode and man's welfare.Nigerian journal of Nematology (2. 3-7).

[8] Egunjobi, O.A 1974. Nematodes and maize growth in Nigeria. Population dynamics of Pratylenchusbrachyurus in and about the roots of maize at Ibadan.Nematologica, 20. 181-186.

[9] Eisenback J.D and H.H Triantaphyllou, 1991. Root knot nematode ,M. spp In. Nickkle, W.R (ed). Manual of Agric helminthology. Marcel Dekker, New York. Pp. 191-274

[10] Emeka, O.M (2007). Improving the agricultural sector towards economic development and poverty reduction in Nigeria. CBN Bullion 4 23-56, FAOSTAT.

[11] FAO (2006) World agriculture: towards 2030/2050 interim report. Global Perspective Studies Unit, FAO, Rome

[12] Fawole, B. 1992. An overview of plant Nematology in Africa. In Fawole, B., Egunjobi, O.A., Adesiyan, S.O and Idowu, A.A.,eds. Proceedings of the first regional symposium on the biology and control of nematode pest of food crops.

[13] Gowen, S.R., Q. Patrick., Fogan, R . 2005. Nematode parasites of banana and plantain. In plant parasitic nematodes in sub-tropical and tropical agric. $2^{\text {nd }}$ edition ( eds M. luc, R.A Sikora, J. Bridge).

[14] Jacobson, M. 1988. Focus on photochemical pesticide vol. 1. The neemtree . Jacobson, M (ed) CRC press BocaRaton, Florida 1989. Pp135-153.

[15] McDonald AH, Nicol JM (2005) Nematode parasites of cereals. In: Luc M, Sikora RA, Bridge J (eds) Plant parasitic nematodes in subtropical and tropical agriculture. CABI Publishing, Wallingford, pp 131-191

[16] Nicol, J.M (2002). Important nematode pests. In: Curtis BC, Rajaram S, Gómez M (eds) Breadwheat improvement and production. FAO Plant Production and Protection Series 2002, p 567

[17] Nwauzor, E.C and Fawole, B 1992. The development and life cycle of Meloidogyne incognita (race2) in D.rotundata var. okwocha. In Fawole, B., Egunjobi, O.A., Adesiyan, S.O and Idowu, A.A.,eds. Proceedings of the first regional symposium on the biology and control of nematode pest of food crops. 127-133.

[18] Nwauzor, E.C 1982.Identification, Biology AND Control of root knot nematodes on edible yams in eastern Nigeria. Ph.D thesis, U.I Ibadan, Nigeria.

[19] Oerke, E.C., Dehne, H.W., Schonbeck, F., and Weber, A. (1994). Crop production Estimated losses in major food and cash crops. Elservier Science, Amsterdam. 808pp.

[20] Ogbuji R.O (1976), The status of root knot nematodes in Eastern states of Nigeria. Proceedings of the research planning conf. on RKN, M.spp. P44-47. June 7-1, 1976.IITA Ibadan.

[21] Olowe T., 1976).Research work on root knot nematode at the National Research Institute.Pp1519. In proceedings of the IMP Research planning conference on Root Knot nematode, $M$. spp, june 7-11,1976, Ibadan Nigeria.

[22] Onyenobi, F.I 1996. Chemical control of yam biodeterioation at cultivation. O.P.P press W.A Ltd. 55 Ogui Rd Enugu.

[23] Onyenobi, F.I (1992). Root knot nematode. An economic problem in Nigeria, In the biology and control ofnematode of food crops in Nigeria, Pp37-48.

[24] Salako, E.A 2002. Plant protection for the resource poor farmers. A key note address @ Nigeria Society for plant protection. $30^{\text {th }}$ Annual conference.UNAAB, Abeokuta, Nigeria. Sept 1-4. 
[25] Salawu, E.O 1992. Preliminary studies on the effectiveness of some medicinal plant extracts as inhibitors of egg hatch in Heterodera in Nigeria. In. The biology and control of nematode pest of food crops in Africa. Pp193-195.

[26] Sasser, J.N. 1989. Plant parasitic nematodes. The farmer's Hidden Enemy. A cooperative publication of the Department of Plant Pathology and the consortium for International Crop Protection, Raleigh, NC., USA.

[27] Schmidt G.H 1986. Pestizide und umweltschutz.Verlag.Brauscheig.

[28] Sogut, M.A and Elekeioglu I.H, 2007. Methyl bromide alternatives for controlling Meloidogyneincogita in pepper cultures in the Eastern Mediterranean Region of Turkey. Turk journal of Agriculture and Forestry 31, 31-40.

[29] Yaradua, A.A2007. Potentials of biopesticides from neem in sustainable pest \& disease management in Nigeria. In medicinal plant in Agric proceedings. ${ }^{\text {rd }}$ SAAT annual conference ., 2007. Pp237-254.

Citation: D. N. Aghale, " Plant Parasitic Nematode Threat to Nigerian Agricultural Food Security ", International Journal of Advanced Research in Botany, vol. 3, no. 3, p. 7, 2017. http://dx.doi.org/10.20431/2455-4316.0303003

Copyright: () 2017 Authors. This is an open-access article distributed under the terms of the Creative Commons Attribution License, which permits unrestricted use, distribution, and reproduction in any medium, provided the original author and source are credited. 